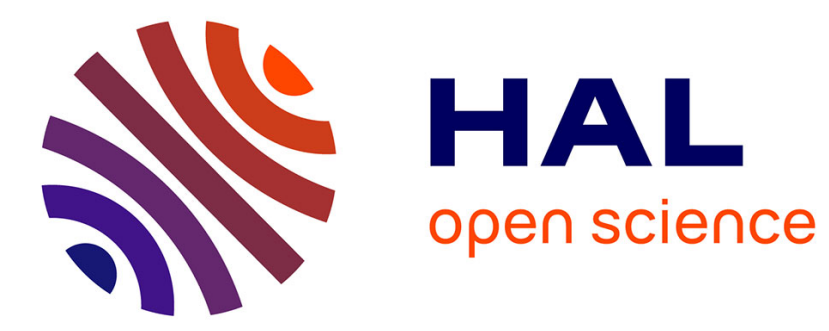

\title{
Local Government and Innovation: the case of Italian provinces
}

Fortuna Casoria, Marianna Marino, Pierpaolo Parrotta, Davide Sala

\section{To cite this version:}

Fortuna Casoria, Marianna Marino, Pierpaolo Parrotta, Davide Sala. Local Government and Innovation: the case of Italian provinces. 2019. halshs-02278092

\section{HAL Id: halshs-02278092 \\ https://shs.hal.science/halshs-02278092}

Preprint submitted on 4 Sep 2019

HAL is a multi-disciplinary open access archive for the deposit and dissemination of scientific research documents, whether they are published or not. The documents may come from teaching and research institutions in France or abroad, or from public or private research centers.
L'archive ouverte pluridisciplinaire HAL, est destinée au dépôt et à la diffusion de documents scientifiques de niveau recherche, publiés ou non, émanant des établissements d'enseignement et de recherche français ou étrangers, des laboratoires publics ou privés. 
UMR 5824

$$
\begin{array}{r}
\text { 93, chemin des Mouilles } \\
69130 \text { Ecully - France } \\
\text { Maison de r'Université, Bâtiment B } \\
10, \text { rue Trefilerie } \\
42023 \text { Saint-Etienne cedex } 02 \text { - France } \\
\text { http://www.gate.cnrs.fr } \\
\text { gate agate.cnrs.fr }
\end{array}
$$

\title{
Local Government and Innovation: the case of Italian provinces
}

\author{
Fortuna Casoria, Marianna Marino, Pierpaolo Parrotta, Davide Sala
}

\begin{abstract}
:
This paper evaluates the effect of decentralization on innovation at the provincial level in Italy. We exploit quasi-natural experiments associated with three waves of reforms occurred in 1992, 2001 and 2004, to establish 8, 4, and 3 new provinces, respectively. Using a difference-in-difference estimation approach, we find evidence of a significant detrimental effect of (further) decentralization on innovation for Northern and Central Italian provinces. We suggest a potential mechanism that may explain the reduction in innovation associated with the aforementioned reforms. We argue that this finding can be rationalized with the costs imposed by the Imafia transplantation" phenomenon, as we find that the new provinces that were more exposed to Imafiosi in confino" reduced their innovation output more extensively. We perform a number of robustness checks that corroborate our main findings.
\end{abstract}

\section{Keywords:}

local government, decentralization, innovation, mafia transplantation, difference-in-difference

JEL codes:

D72, H72, K42, O31

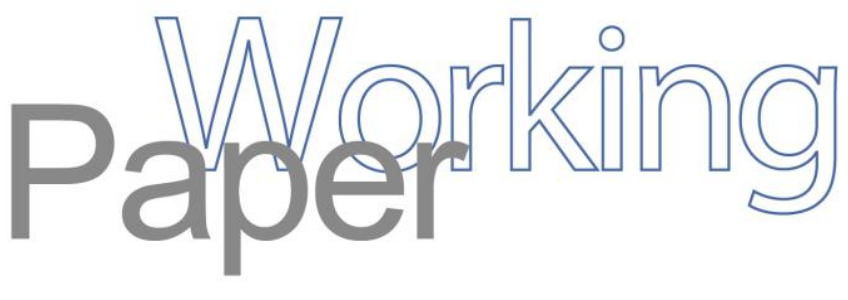




\title{
Local Government and Innovation: the case of Italian provinces*
}

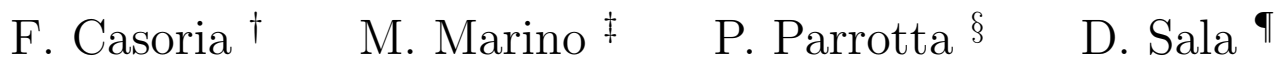

\begin{abstract}
This paper evaluates the effect of decentralization on innovation at the provincial level in Italy. We exploit quasi-natural experiments associated with three waves of reforms occurred in 1992, 2001 and 2004, to establish 8, 4, and 3 new provinces, respectively. Using a difference-in-difference estimation approach, we find evidence of a significant detrimental effect of (further) decentralization on innovation for Northern and Central Italian provinces. We suggest a potential mechanism that may explain the reduction in innovation associated with the aforementioned reforms. We argue that this finding can be rationalized with the costs imposed by the "mafia transplantation" phenomenon, as we find that the new provinces that were more exposed to "mafiosi in confino" reduced their innovation output more extensively. We perform a number of robustness checks that corroborate our main findings.
\end{abstract}

JEL Classification: D72, H72, K42, O31.

Keywords: local government, decentralization, innovation, mafia transplantation, differencein-difference.

\footnotetext{
*We are grateful to the participants of the UCL macro lunch seminar (Louvain-la-Neuve, April 2018), LISER research seminar (Luxembourg, February 2019), and University of Calabria (Rende, May 2019). The usual disclaimer applies.

${ }^{\dagger}$ University of Lyon, CNRS, GATE UMR 5824, F-69130 Ecully, France. E-mail: casoria@gate.cnrs.fr

${ }^{\ddagger}$ Corresponding author. SKEMA Business School - Université Côte d'Azur, Avenue Willy Brandt, 59777 Euralille, France. E-mail: marianna.marino@skema.edu

${ }^{\S}$ IESEG School of Management, 3 rue de la Digue, 59000 Lille, France; LEM-CNRS 9221; IZA; ROA; NoCeT. Email: p.parrotta@ieseg.fr

ๆ University of Passau, 94030 Passau, Germany. E-mail: davide.sala@uni-passau.de
} 


\section{Introduction}

It is widely accepted among scholars in social sciences that the establishment of subnational tiers of government improves the overall economic efficiency in the provision of public goods or services (Bardhan, 2002). ${ }^{1}$ Among the most recognized advantages of decentralization is the higher ability of local government to (i) match public spending to the heterogeneous preferences of individuals or firms - allocative efficiency - and to (ii) mobilize underused resources to compete against other local jurisdictions - productive efficiency (Rodriguez-Pose and Ezcurra, 2010). Local governments may for instance exploit information about territorial conditions, better than the central administration does, to design innovation policies tailored to the specific needs and demands of local innovators or to improve the matching between entrepreneurs with innovative business projects and investors seeking R\&D opportunities (Taylor, 2007).

However, there are a number of countervailing factors that may in practice hinder the achievement of the benefits associated to administrative decentralization. First, there exist incentives to under-report the true willingness to pay in case people or companies fear the actual payment of this public provision (Feld et al., 2004). This argument alone undermines allocative efficiency as the sum of individuals'/firms' true marginal willingness to pay could not be possibly equalized to the actual marginal cost of the public good provision. Second, even if decentralization enhances the matching of the provision of goods and services to the preferences of the population/firms, local governments may be less efficient than the central one in delivering such goods and services due to the loss of economies of scale (Prud'homme, 1995). It is also questionable that different tiers of government may have similar levels of technical and administrative capacity. Moreover, and most importantly for our paper, local administrations are typically weaker and less accountable institutions, with the corruption of public officials resulting easier compared to the case of the national authority, particularly when local governments are empowered to allocate resources among individuals and companies and to bid for greater shares of the national budget (Rodriguez-Pose

\footnotetext{
${ }^{1}$ See the landmark contributions due to Tiebout (1956), Musgrave (1959) and Oates (1972).
} 
and Ezcurra, 2010). Therefore, there is scope within local governments for cronyism and the creation of a system of patronage in the management of public funds to the detriment of the economic efficiency.

This paper centers around the question of whether mismanagement of local funds can overturn the recognized advantage of decentralization. The case of Italy is particularly suitable to address this question, not only because Italy has been historically the host of some of the most influential and powerful criminal organizations worldwide, but also because - and perhaps this is less known - it has undergone important decentralization reforms. Specifically, the combination of the following two events is of particular interest for our research question. The first one is known as the mafia transplantation phenomenon (or also the "Northern Passage" of mafia activities), which indicates that the links between mafia and politics have radicated, from the South of Italy, where they were rooted in, towards the Northern (and richer) regions, where the infiltration of criminal organizations was originally absent. The second event is the administrative reform of the territorial governance that has introduced eight, three, and four new provinces, respectively, in three subsequent waves of reforms $(1992,2001$, and 2004).

These changes in the territorial governance allow us to implement a difference-indifference (DID) estimation strategy and therefore to study the effect of decentralization on innovation, which we consider as an indirect measure of economic efficiency. Key to the implementation of this strategy is that our sampling period spans some years before the first reform (i.e. 1992) through some years after the last reform (i.e. 2004). We proxy innovation output by means of patent applications at the European Patent Office (EPO) over 1977-2012. ${ }^{2}$ The use of patents is strongly grounded in the New Growth Theory that regards the R\&D sector as the primary input for innovation and ultimately as the engine of a sustained economic growth in the long run (Romer, 1990; Lucas, 1988).

In our estimation strategy, we control for province fixed effects and region time-

\footnotetext{
${ }^{2}$ The availability of other data informing on the economic activity at the local level is very scant and certainly does not cover a similarly wide time period. For instance, data on provincial GDP are available only from 2000 onwards (see Eurostat website).
} 
varying effects to account for average differences between provinces and idiosyncratic shocks over time at the regional level, respectively. Additionally, we factor out potential inter-province spillovers by removing provinces that share borders with the new established ones, i.e. we remove the bias associated with the reallocation of resources that may occur among neighbor provinces or due to the province split.

We find evidence of a significantly negative effect of decentralization on innovation. This detrimental effect is however heterogeneous because it varies by reform wave and across macro areas in the Italian territory. More specifically, innovation seems to be significantly hindered mainly in provinces in the Northern-Central regions, which comprise the more economically active areas of the country. Moreover, the overall decentralization effect appears to be exclusively driven by the 1992 reform, which is the wave that introduced the deepest changes in the provincial territory.

Inspired by Buonanno and Pazzona (2014), we relate this finding to the "mafia transplantation" phenomenon thoroughly documented in Dalla Chiesa (2017). The infiltration of criminal organization into the economic and political activities in Northern Region spurred (partly and unintentionally) from the mandatory resettlement-residence ("confino") policy in place until 1970's, to which highly ranked mafia bosses were subjected to. We therefore collected information on bosses sent in confino (i.e. forced exile) to identify with reasonable accuracy, on the basis of anti-mafia parliamentary committee reports, the arrival municipality and associated province of forced exile. The forced exile of bosses has led to the necessity of recreating criminal cells elsewhere employing those strategies and methods already successfully experimented in the Southern regions.

The final result being that higher proximity between organized criminal groups and public officials has favored mafia infiltrations and its illicit activities (e.g. corruption of public authorities, diversion of public funds, unfair competition) with obvious negative consequences on both direct and indirect costs of innovations for knowledge intensive firms located in Northern Italy and investing significant resources in high-risk projects. Consistently with this backdrop, the reduction in local government size due to the reform waves should increase the costs of innovation activities in Northern-Central 
provinces that have been more exposed to "mafiosi in confino".

Indeed, we find evidence of a stronger detrimental effect for new established provinces that have been more exposed to transplanted criminal cells, compared to those less exposed or unexposed to them. Although other potential mechanisms may concur to explain the reduction in innovation output identified for the new Northern-Central provinces, we deem to have nevertheless nailed an important channel, which is at the present still underrated, especially with regard to its international implications. In fact, dynamics similar to those identified on the Italian territory might be at play also in the geographical administrations of other OECD countries, where mafia-type organizations have expanded their illegal businesses (Europol, 2013; Sergi and Lavorgna, 2016).

The reminder of the paper is as follows: Sections 2 and 3 describe the related literature and the institutional background, respectively. Section 4 informs on the deployed estimation strategy; section 5 describes the data used and provides descriptive statistics and evidence concerning the relationship under analysis. Section 6 reports the discussion of our results, and section 7 concludes the paper highlighting potential policy implications of our findings.

\section{Related literature}

The theoretical literature on fiscal federalism typically identifies two major advantages of decentralization. First, decentralization is believed to improve allocative efficiency. By being closer to the citizens, local governments have better information on their preferences, and are therefore better equipped to match such preferences with adequate services (Tiebout, 1956; Musgrave, 1959; and Oates, 1972). Moreover, decentralization supposedly gives voters more control over politicians and allows for yardstick competition, so that voters are able to infer the quality and competence of their politicians by comparing the performance of different local governments (see Besley and Case, 1995 and subsequent literature). Second, it is argued that decentralization may increase productive efficiency by deploying underused resources to perform better than neighbor 
jurisdictions (Rodriguez-Pose and Ezcurra, 2010), and therefore alleviate issues such as waste collection and treatment in local communities. Other scholars have taken a more cautious approach in assessing the benefits of decentralization. Prud'Homme (1995) and Tanzi (1995), for instance, claim that decentralization exposes local governments to greater corruption and lobbying by local interest groups, precisely because of the proximity between such groups and local government officials.

The empirical literature has extensively studied the merits of fiscal decentralization and its relationship with government efficiency. There is broad, yet mixed, evidence on possible links between decentralization and corruption. Huther and Shah (1998) find a negative correlation between the degree of expenditure decentralization and the level of corruption, measured using a governance index for 80 developed and developing countries. However, by focusing on correlations alone, their analysis suffers from omitted variables bias, as it disregards the many factors that could be correlated with both decentralization and corruption. Mello and Barenstein (2001) find that decentralization is negatively correlated with corruption (measured using the International Country Risk Guide - ICRG - index), ${ }^{3}$ but that this effect depends on how subnational expenditures are financed. In particular, they show that there is a strong negative association between decentralization and corruption when subnational spending is financed with non-tax revenues. Fisman and Gatti (2002) examine a cross-country relationship between decentralization and corruption (also measured using the ICRG index). They find that decentralization is significantly associated with less corruption, but also that, conditional on the degree of fiscal decentralization, being a federal country has no significant effect on corruption. In these studies, the level of fiscal decentralization is measured by the percentage of government expenditures made at the subnational level, as recorded by the IMF's Government Financial Statistics. Treisman (2000) takes a different approach by accounting for a country federal structure. He uses an average of various corruption indices, and a dummy variable to indicate whether a country has a federal or unitary structure. He finds that federalist countries have higher rates

\footnotetext{
${ }^{3}$ The ICGR is published by Political Risk Services, a business risk and forecasting organization that surveys business people and experts asking questions about levels of corruption in different countries.
} 
of corruption. However, Treisman (2000)'s simple measure of decentralization may not accurately reflect the extent to which subnational governments have authority or autonomy in decision-making. Treisman (2002), instead, uses several constitutional indicators of decentralization (such as a dummy variable for a federal country and the number of tiers of government) and the World Bank corruption index. His results suggest that corruption is perceived to be higher in countries with more tiers of government.

Other studies take a broader perspective, and show that fiscal decentralization may be positively correlated with different indicators of good government. Barankay and Lockwood (2007) use a dataset of Swiss cantons and show that there is a positive relationship between fiscal decentralization and education. Robalino and Picazo (2001), Asfaw et al. (2007), Cavalieri and Ferrante (2016) find a positive association between decentralization and health outcomes, measured by infant mortality rates. ${ }^{4}$

While the link between fiscal decentralization and government efficiency has received wide attention, the relationship between decentralization and technological innovation is largely unexplored. Theorists support the idea of a positive correlation between decentralization and innovation (see, for instance, Acemoglu et al., 2005). Empirical evidence is so far limited to case studies, most of which do not establish a direct link between decentralization and innovation. The case study by Drezner (2001) represents an attempt at doing so. He tests the hypothesis that decentralized states are better suited to fostering innovation by looking at the United Kingdom-Germany rivalry for technological leadership in the XIX century, and at the US-Japan rivalry of the last decades. Drezner (2001) highlights that in both cases the more centralized state had difficulties over time to emerge as technological leader. Taylor (2007) provides a more rigorous analysis of the relationship between fiscal decentralization and innovation. He studies whether a general correlation between innovation and decentralization exists by using data from the European Patent Office, data on scientific publications,

\footnotetext{
${ }^{4}$ Robalino and Picazo (2001) use a panel of low- and high-income countries; Asfaw et al. (2007) study infant mortality rates in India, while Cavalieri and Ferrante (2016) consider Italy as institutional context.
} 
and high-technology exports that cover a span of 17 years. In particular, the data refer to five of the most decentralized industrialized countries (Australia, Canada, Germany, Switzerland, United States) and to five of the most centralized ones (Finland, France, Great Britain, New Zealand, Sweden). Taylor (2007) shows that decentralized states are not more innovative than centralized states. A further relevant contribution is due to Prud'homme (2016), who uses economic decentralization theories to evaluate the effectiveness of industrial specialization policies implemented within each of mainland China's 31 provinces. He finds that the Chinese system of economic decentralization has either facilitated the technological catching-up of some provinces or led to the deployment of risky or even likely ineffective industrial development strategies.

In our paper, we empirically assess the effect of fiscal decentralization on innovation in the context of Italian provinces by exploiting the establishment of new provinces occurred in the over 1977-2012 time period. Two papers, Barone (2011) and Caglayan et al. (2017), are closely related to ours. Barone (2011) uses this same quasi-experiment and finds that the creation of new provinces in 1992 has not brought any benefits in terms of population growth, share of population that completed mandatory education, and quality of the roads. Differently from Barone (2011), we focus on the performance of Italian provinces in terms of innovation (i.e. number of patent applications) and use all reform waves implemented to establish new provinces over the years. Caglayan et al. (2017) provide empirical evidence that a greater presence of organized crime is related to lower innovation and firms technological level during 2005-2012. Similarly to Caglayan et al. (2017), we approximate the increase in the presence of organized crime with the number of mafiosi in confino, i.e. individuals who were forcedly resettled in areas other than the municipalities of residence (from Southern to Central and Northern Italian provinces) because convicted or strongly suspected to belong to criminal organizations. ${ }^{5}$ Our paper differs from Caglayan et al. (2017) in at least two elements. First, we implement a different estimation strategy, which exploits the afore-

\footnotetext{
${ }^{5}$ Buonanno and Pazzona (2014) use the number of mafiosi in confino to explain mafia transplantation to Central and Northern Italian regions; Scognamiglio (2018) uses it to analyze how the arrival of members of crime organizations affects the local economy, and find a positive effect on employment in the construction industry.
} 
mentioned quasi-experimental design and that allows for the identification of a causal effect. Second, our main analysis is based on all Italian provinces and covers a longer time span.

\section{Institutional context}

Italy has a three-tier system of territorial governance, which includes regions, provinces and municipalities. ${ }^{6}$

According to the principles established by the Constitution, regions, provinces, and municipalities are autonomous bodies with their own statutes, powers and functions. Both the State and the regions exercise legislative power; but the legislative power of regions is limited to matters not expressly reserved to the legislation of the State. Municipalities, provinces, and regions have financial autonomy for revenues and expenditure. Specifically, they establish and apply their own taxes and manage their own income, according to the principles of coordination of public finance and the tax system. ${ }^{7}$

At the birth of the Italian Republic there were 19 regions, which largely corresponded with the territorial entities of the former Kingdom of Italy. In 1963, the "Abruzzi and Molise" region was divided into the two regions of Abruzzo and Molise, increasing the number of regions to 20 , which has not been subject to changes. ${ }^{8}$

For about twenty years after the end of the World War II, the provincial geography of the Italian Republic remained substantially unchanged. ${ }^{9}$ Subsequent changes in the provincial geography occurred in 1968, in 1970 and 1974 with the establishment of

\footnotetext{
${ }^{6}$ With the term "province" we refer to the provincial administrative level labeled with the NUTS 3 code by Eurostat.

${ }^{7}$ Titolo V - Le Regioni, le Province e i Comuni http://www.governo.it/costituzione-italiana/ parte-seconda-ordinamento-della-repubblica/titolo- v-le-regionile-province-e-i.

${ }^{8}$ https://dait.interno.gov.it/territorio-e-autonomie-locali/sut/1963.pdf.

${ }^{9}$ The sole exception is the (part of the old) province of Trieste, which was reintegrated into the Italian national territory as a result of the London Memorandum in 1954. http://freeterritorytrieste. com/TREATIES/UN541005MEMORANDUMLONDRA.pdf.
} 
the provinces of Pordenone (Veneto), ${ }^{10}$ Isernia (Molise) ${ }^{11}$ and Oristano (Sardinia), ${ }^{12}$ respectively. A first major re-definition in the size and number of provinces was introduced in 1992, when 8 new provinces were added to the existing 95 - Biella and Verbano-Cusio-Ossola (Piedmont), ${ }^{13}$ Crotone and Vibo Valentia (Calabria), Lecco and Lodi (Lombardy), Prato (Tuscany), and Rimini (Emilia Romagna). ${ }^{14}$ These new administrations became operational in 1995. A second reform wave occurred in 2001 and affected exclusively the territory of Sardinia, where 4 new provinces (Olbia-Tempio, Ogliastra, Medio Campidano and Carbonia-Iglesias) were established. They became operational in 2004 and represented the first experience of new provinces created by regional law, which led to a series of coordination issues with the national legislation. ${ }^{15}$ The third and last major redefinition of the provincial geography occurred in 2004, when the total number of geographical provinces increased to 110, with the inclusion of 3 new provinces - Monza and Brianza (Lombardy), Fermo (Marche) and BarlettaAndria-Trani (Apulia) - that became operational a few years later. ${ }^{16}$ In 2012, people in Sardinia voted for the abolition of the 4 provinces established in 2001. The output of this referendum had however effect only in 2016, when the province of Sud Sardinia was created with the contextual redefinition of the province of Cagliari. ${ }^{17}$ The current number of Italian provinces (including the metropolitan areas) is 107.

For the purpose of our study, we focus on the three main waves of reforms that have affected the Italian provincial geography, namely the ones approved in 1992, 2001 and 2004. Since several other laws may have had an impact on the actual power and functions of the provinces over time, in our analysis we also account for such changes (which however applied simultaneously to all provinces at the national or regional level). ${ }^{18}$

\footnotetext{
${ }^{10} \mathrm{https}$ ///dait.interno.gov.it/territorio-e-autonomie-locali/sut/1968.pdf.

${ }^{11}$ https://dait.interno.gov.it/territorio-e-autonomie-locali/sut/1970.pdf.

${ }^{12}$ http://www.normattiva.it/uri-res/N2Ls?urn:nir:stato:Legge:1974-07-16;306.

${ }^{13}$ http://www.gazzettaufficiale.it/eli/gu/1992/05/08/106/sg/pdf.

${ }^{14}$ http://www.gazzettaufficiale.it/eli/gu/1992/04/01/77/sg/pdf.

${ }^{15}$ http://www.gazzettaufficiale.it/eli/gu/2001/07/11/27/s1/pdf.

${ }^{16}$ https://dait.interno.gov.it/territorio-e-autonomie-locali/sut/2004.pdf.

${ }^{17}$ http://consiglio.regione.sardegna.it/XVLegislatura/Leggi_approvate.asp.

${ }^{18}$ See Section 4, which reports our estimation strategy.
} 
Over our sample period, the functions of the provinces were: protection and enhancement of the environment (soil, water, energy resources) and prevention of disasters; enhancement of cultural heritage; transports; organization of waste disposal (detection, discipline and control of discharges of water and atmospheric emissions); health, hygiene and public prophylaxis services; education (including school buildings); data collection and processing, technical and administrative assistance to local authorities; promotion and coordination of productive, commercial, tourism as well as social and cultural activities.

In 2014, the Italian government approved a local government reform that has substantially redesigned the functions of provinces. ${ }^{19}$ According to the new law, several matters provinces had competence on have been transferred to regions and municipalities. However, provinces are still in charge of the territorial planning (coordination, defense and enhancement of the environment), the planning of transport services, the construction and maintenance of provincial roads.

\section{Estimation strategy}

To identify the effects of the three main reforms of provincial geography on firm innovation, we deploy a difference-in-difference estimation approach. Specifically, we estimate the following linear model:

$$
\begin{array}{r}
\text { PatApps }_{i t}=\alpha+\text { Breated }_{i}+\theta_{1} \text { post }_{-} 92_{t}+\theta_{2} \text { post_0 }_{-} 1_{t}+\theta_{3} \text { post }_{-} 04_{t}+ \\
\delta \text { treated } \times \text { post }_{\mathbf{i t}}+\eta_{t} \times \xi_{k}+u_{i}+v_{i t} .
\end{array}
$$

PatApps indicates the number of patent applications at EPO, which varies over time at the provincial level; treated is a dichotomous variable that takes value 1 if the province is/will be a "new province"; post_92, post_01, and post_04 are dummy variables indicating each post-treatment period; the interaction treated $\times$ post is our treatment

\footnotetext{
${ }^{19}$ http://www.gazzettaufficiale.it/eli/gu/2014/04/07/81/sg/pdf.
} 
variable, shown in bold in model (1). We are interested in the sign and size of the parameter $\delta$, which informs on the treatment effect associated with the birth of new provinces, regardless of the wave. To account for potential time-varying region specific effects we include the interaction term $\eta \times \xi$. The term $u$ controls for time-invariant province fixed effects, while the term $v$ is an idiosyncratic term.

We also perform an alternative and more detailed specification of the model (1), where both treated and the interaction treated $\times$ post are split into three components, depending on whether we refer to the first, the second, or the third reform wave. This more flexible specification, model (2), allows us to identify the treatment effects associated with each reform and to capture the potential heterogeneity in their impact.

$$
\begin{aligned}
& \text { PatApps } s_{i t}=\alpha+\beta_{1} \text { treated_92 } 2_{i}+\beta_{2} \text { treated_01 } 1_{i}+\beta_{3} \text { treated_0 } 4_{i}+ \\
& \theta_{1} \text { post_92 } 2_{t}+\theta_{2} \text { post_0 } 1_{t}+\theta_{3} \text { post_0 } 4_{t}+\delta_{1}(\text { treated } \times \text { post_92 } \mathbf{i t})+ \\
& \delta_{2}\left(\text { treated } \times \text { post } \_01_{\mathbf{i t}}\right)+\delta_{3}\left(\text { treated } \times \text { post } \_04_{\mathbf{i t}}\right)+\eta_{t} \times \xi_{k}+u_{i}+v_{i t} .
\end{aligned}
$$

\section{Data}

\subsection{Data sources}

We retrieve data on patent applications at the European Patent Office (EPO), measured at the provincial (NUTS 3) level over the 1977-2012 time period, from the EUROSTAT website "Science and Technology". ${ }^{20}$ We are aware that using patent applications implies that only certain types of innovations, from a limited range of industries, are taken into account. We acknowledge as well that, since a number of firms may prefer secrecy over patenting, some of the data might not be available. On the other hand, patent applications are subject to formal tests of novelty and non-obviousness, and they are a good proxy of the companies' research efforts, which often result into

\footnotetext{
${ }^{20}$ Patent statistics derive from the raw database PATSTAT, see https://ec.europa.eu/eurostat/web/ science-technology-innovation/data.
} 
successful innovations.

Information on the institutional change of the Italian provincial geography is obtained from the website of the Ministry of the Interior. ${ }^{21}$ A careful analysis of the anti-mafia parliamentary committee reports allowed us to collect data on the number of convicted high-rank bosses who faced forced exile (confino) to Northern and Central provinces until mid-70's. As in Buonanno and Pazzona (2014) and Scognamiglio (2018), we use the number of mafiosi in confino to identify the provinces that were more/less exposed to the transplantation of organized crime. This measure of mafia exposure is not free from criticism. Indeed, since it has not been kept track of every boss who moved to the North independently, the aforementioned parliamentary reports do not provide a comprehensive accounting on all resettlements from the historical mafia regions (Dalla Chiesa, 2017). Although we share this concern, we deem the information retrieved in these reports to be reliable and valuable in order to identify the areas that have been highly exposed to the pressures and activities of criminal groups led by top mafia bosses.

\subsection{Descriptive statistics and evidence}

Figures 1-3 show the geographical position of the new provinces by reform wave.

\section{[Figures 1-3 about here]}

Descriptive statistics on treated provinces by reform wave are reported in Table 1 (in alphabetical order). Pre- and post-treatment periods are balanced around the reform year, 7 years per time window, respectively: 1986-1992 and 1993-1999 for the 1992 reform; 1995-2001 and 2002-2008 for the 2001 reform; and 1998-2004 and 2005-2011 for the 2004 reform. A general increase in the average number of patent applications is observable when comparing before- and after-reform periods. The provinces Monza and Brianza and Barletta-Andria-Trani represent two extreme cases: the former experiences an increase in the number of applications of more than $300 \%$, whereas the latter reports

\footnotetext{
${ }^{21}$ http://www.interno.gov.it/en.
} 
a value of 0 applications for both periods. This is consistent with the evidence that Southern provinces typically show a smaller raise in their innovation activities than Northern ones.

\section{[Table 1 about here]}

A broader picture of the contribution of each province to the national innovation outcome emerges from Table A1, which informs on the ranking (ascending order) by average patent applications at EPO over the period 1986-2012. This table shows that the 5 least innovative provinces are new ones, and all of them are located in Southern Italy. The most innovative new provinces are either in Lombardy (Lecco and Monza and Brianza are 81st and 82nd, respectively) or in Emilia Romagna (Rimini is 73rd). Figure A1 translates into a geographical dimension what just discussed for Table A1.

It is worth noting that systematic differences between treatment (new provinces) and control groups (old provinces) in the sample are not an issue for the implementation of the DID approach, which does require a random assignment to treatment (Angrist and Pischke, 2008; and Cameron and Trivedi, 2005). Instead, a key identifying assumption is that treatment and control groups show similar trends prior to the treatment (parallel trends assumption). We provide descriptive evidence concerning parallel trends in Figures 4-6, which show linear fits of patent applications for both treated (blue dots) and controls (red dots) by reform wave. Parallel trends appear to emerge only for the 1992 reform. For the 2001 reform, non-parallel trends are particularly stark, as we observe a clear divergence in the pre-treatment values of patent applications between the two groups of provinces. The 2004 reform also shows nonparallel trends, it is however interesting to notice that the slope of the trend associated with old provinces turns negative after 2004, whereas the slope associated with new provinces becomes steeper in the after-reform period. This may suggest that the slight divergence in the pre-treatment period is not due to an anticipation effect in terms of innovation potential for the areas set to become provinces. 


\section{Results}

Our main findings are reported in Tables 2 and 3, which show the average treatment effects carried by the interaction terms over different specifications. Table 2 reports the average overall treatment effect (i.e., the parameter $\delta$ ), while Table 3 reports the average treatment effect by reform wave (i.e., $\delta_{1}, \delta_{2}$ and $\delta_{3}$ ). Standard errors are all clustered at the provincial level, which is the unit of analysis for each observational year in our sample period 1977-2012. In Table 2, we gradually augment the DID specification with no control variables (base specification) either by adding further covariates or by removing the 5 provinces that innovate the most, namely Milan, Turin, Bologna, Rome and Vicenza. More specifically, we sequentially (a) add to the base specification, column (i), time and province fixed effect, column (ii); (b) replace time with region-time specific effects, column (iii); (c) exclude the top 5 performers, column (iv). The inclusion of province fixed effects substantially improves the explanatory power of our model, which jumps from $3 \%$ to $81 \%$ and remains relatively stable in the subsequent specifications. The treatment effect is always negative and increases in its numerical value when we account for time-varying region specific effects, even though the point estimate becomes somewhat less precise. Once we exclude the top 5 performers, the coefficient estimate decreases by about a third of its size. We deem the estimate in specification (iv) to be the most reliable, as the underlying model allows for a better comparability between treatment and control groups. This estimate suggests that becoming a new province may decrease the number of patent application at EPO by about 6.5 units, as compared to the old provinces. Taking into account the already rather low average number of patent applications observed in the Italian territory, a reduction of this magnitude in our innovation measure is undoubtedly relevant.

\section{[Table 2 about here]}

In Table 3, we report the treatment effect by reform wave. The more flexible and informative model is reported in column (i), where we use the same covariate set as we did in the last specification of Table 2. Interestingly, we find that the overall treatment 
effect is driven exclusively by the 1992 reform. Indeed, the treatment effects associated with the two more recent waves are much smaller and not statistically significant. We find that, on average, a province created in 1992 experiences a significant decrease in the number of patent applications of slightly more than 9.5, with respect to old provinces. This reduction appears to be less pronounced if we shorten the time window and look at the 1986-2012 period. The justification for this restriction is twofold. First, patent applications at EPO are filed in more systematically from 1985 onward. ${ }^{22}$ Secondly, the shortening of the time span improves the parallelism in pre-treatment innovation trends between new and old provinces. ${ }^{23}$ A confounding effect might come from the potential influence of geographical spillovers: externality effects associated with firms' location decisions or labor mobility are likely to affect neighbor provinces. Conceptually, these effects may significantly bias our estimates either upward or downward, depending on whether innovative companies or workers decide to move to/from new born provinces from/to old ones. In order to control for such effects, we exclude neighbor provinces from the sample and re-estimate the model in column (iii). ${ }^{24}$ It is worth noticing that, by dropping neighbor provinces off the sample, the size of economic activity (i.e. agglomeration economy effect), related to the split from "donor" provinces, drops as well. After the exclusion of neighbor provinces, we find that the absolute magnitude of the 1992 reform effect almost doubles, i.e. a province born in 1992 reduces its patent applications by about 11 units on average, compared to an old province. This entails that the aforementioned externality effects bias downward the estimates reported in columns (i) and (ii).

Therefore, taking the specification related to column (iii) as our preferred one, we now test whether such negative treatment effects are geographically heterogeneous. Besides being relevant on its own, the rationale for this check finds roots in the his-

\footnotetext{
${ }^{22}$ See Eaton et al. (2004).

${ }^{23}$ Figures 4-6 report the same time span.

${ }^{24}$ We define as neighbor any old province sharing a border with a new one. The set of neighbor provinces includes Arezzo, Ascoli Piceno, Bari, Bergamo, Bologna, Cagliari, Catanzaro, Como, Cosenza, Cremona, Florence, Foggia, Forl-Cesena, Macerata, Milan, Novara, Nuoro, Oristano, Pavia, Pesaro and Urbino, Piacenza, Pistoia, Potenza, Reggio di Calabria, Sondrio, Turin, Valle d'Aosta/Valle d'Aoste, Varese, Vercelli.
} 
torical Italian North-South economic divide. We regress our preferred specification on Southern-Central, column (iv), and Northern-Central regions, column (v), separately. ${ }^{25}$ Somewhat unexpectedly, it turns out that the 1992 reform effect is completely led by Northern-Central regions. More specifically, while the parameters in column (v) are similar to those reported in column (iii), ${ }^{26}$ no significant treatment effects are found for Southern-Central regions, column (iv). We consider this finding as particularly relevant because it suggests that innovation is hindered the most in more developed areas of the country, where apparently several productive companies in new provinces lower their innovation output, as compared to those in the control group. Conversely, innovation activities in more depressed regions are not significantly affected by the change in the provincial geography.

\section{[Table 3 about here]}

In this regard, it is interesting to understand the potential mechanism behind our results, i.e. to identify what factors may have caused a reduction in innovation activities in Northern-Central regions. Inspired by the papers studying the phenomenon of mafia transplantation in Italy (see Buonanno and Pazzona, 2014; and Dalla Chiesa, 2017), we test whether the exposure of provinces in Northern-Central regions to the influent mafia bosses sent in confino may provide a partial explanation to our findings. It is worth mentioning that highly ranked mafia bosses were sent in confino until mid-1970s (i.e. much earlier than the start of our sample period), and that, to our knowledge, the level of economic activity characterizing the arrival provinces was not a selection criterion (i.e. local economic development was orthogonal to the inflow of influent mafiosi). We look at mafia transplantation as potential mechanism because mafia activities may contribute to increasing the cost of innovation in at least three ways: by making use of extortions or by imposing their input suppliers to firms; by corrupting public authorities

\footnotetext{
${ }^{25}$ Northern-Central regions include: Emilia Romagna, Friuli Venezia Giulia, Liguria, Lombardy, Marche, Piedmont, Trentino Alto Adige, Tuscany, Umbria, Valle d'Aosta, Veneto. The SouthernCentral area comprises the complementary set of regions.

${ }^{26} 2001$ treatment effects are not estimated for Northern-Central regions because the variation to identify such an effect is due to Sardinia, which is a region in the complementarity subset.
} 
and diverting public funds; and by promoting illegal and unfair competition. Thus, the establishment of a new province may increase the proximity of the transplanted mafia organization to the local authority, facilitating de facto the potential corruption of public officials or other illegal activities expected to hinder knowledge accumulation and innovation output. In Table 4, we split provinces in Northern-Central regions in 'abovemedian', 'between median and 1st quartile', and 'below 1st quartile' exposure to mafiosi in confino and run our preferred specification. This sample split is somehow driven by the number of new provinces included in each category: Lodi, Monza and Brianza in the 'above-median'; Biella and Lecco in the 'between median and 1st quartile'; and Fermo, Prato, Rimini, and Vebano-Cusio-Ossola in the 'below 1st quartile'. Consistently with the idea that mafia transplantation increases the innovation costs, we find that the new provinces that have been more exposed to mafiosi in confino significantly reduce their innovation output. This reduction amounts to about 17.7 patent applications for the 'above-median' category, and to about 10.7 and 1.1 for the remaining ones, respectively. Although the estimates are not significant for the last two categories, we find evidence of a monotonic decrease in the absolute value of the treatment effect with respect to mafia exposure at the provincial level.

\section{[Table 4 about here]}

Finally, we report a number of robustness checks in Table 5. Specifically, columns (i) and (ii) show placebo tests to check the robustness of our main findings to a random assignment of the "new province" status to old provinces, maintaining the regional composition. This means that we treat new provinces as old ones, and some pre-existing provinces as new ones, while making sure that the number of new provinces remains the same within a region. We find no significant effects of placebo testing of models (1) and (2), i.e. for pooled and by wave estimates associated with randomly assigned treatment units. Column (iii) informs on the correlation between patent applications and mafiosi in confino on the pre-treatment period 1986-1992. This correlation is sizeable and significantly negative, supporting the hypothesis that provinces experiencing 
mafia transplantation to a higher extent show lower levels of innovation output. Lastly, in column (iv) we display the treatment effects from our baseline specification while disregarding the years related to the recent economic crisis (2009-2012). These estimates are in line with our main findings. Overall, the performed robustness checks corroborate our main results.

[Table 5 about here]

\section{Discussion and conclusions}

In this paper, we shed light on the impact of decentralization on innovation by focusing on the case of Italian provinces. More specifically, we use data on patent applications at the EPO (measured at the NUTS 3 level), and exploit changes in the provincial geography of the Italian territory, which occurred in different waves (1992, 2001 and 2004), to perform an empirical analysis that compares the innovation outcome between newly established and old provinces. By means of a DID estimation strategy, which accounts for province time-invariant and region time-varying effects as well as for interprovince spillover confounders, we find evidence of a significant detrimental effect of decentralization on innovation. This effect is quite heterogeneous as it varies both geographically and by reform wave. Indeed, it turns out that whereas decentralization significantly hinders innovation in provinces in Northern-Central regions (the more economically active areas of the country), it does not affect innovation in SouthernCentral provinces. Moreover, we find that the decentralization effect seems to be entirely driven by the 1992 reform, which has been though the most extensive wave as it involved more regions than other waves did.

Although our findings may be the result of different mechanisms at play, we decided to dig deeper in our investigation by collecting information from anti-mafia parliamentary committee reports on the number of highly ranked mafia bosses who were subject to forced exile to municipalities in Northern-Central provinces. This mandatory 
resettlement-residence ('confino') policy that was in place until 1970's, well before the start of our sample period, unintentionally favored a process of mafia transplantation, as documented in Buonanno and Pazzona (2014) and Dalla Chiesa (2017). Furthermore, assuming that the level of economic development was not a selection criterion of the municipalities where such powerful 'mafiosi' were sent to, we deem reverse causation not to be an issue in our analysis. Thus, we consider mafia transplantation as potential mechanism involved because it may had increased innovation costs through the corruption of public authorities, the diversion of public funds, the promotion of unfair competition, and other illicit activities. We find evidence that newly established Northern-Central provinces that have been more exposed to mafiosi in confino suffered higher detrimental effect of decentralization, compared to the less exposed ones. This is consistent with the idea that corruption and collusion may be easier to organize and enforce in smaller subnational government domains, due to the higher proximity of public officials and various interest groups, even in areas with a relatively high level of economic development. Therefore, the reduction in local government size due to the reform waves may have favored the aforementioned illegal activities, increasing de facto the mafia's influence on the new provinces. It is worth emphasizing that the identification of the role of mafiosi in confino does not exclude other potential complementary mechanisms that we are not able to test in this study.

Our findings are policy relevant and provide recommendations not only to the Italian public administration but also to the territorial governance of several European and OECD countries that in the last decades have been widely infiltrated by mafia groups, as documented in the Europol's threat assessment on the Italian organized crime (Europol, 2013). Indeed, there exist increasing evidence of an ongoing process of transplantation on a global scale through the exploitation of foreign territories and communities which are silently under the control of Italian mafias (e.g. see Sergi and Lavorgna, 2016). Future studies in our agenda will shed more light on some of the consequences of this transplantation process. 


\section{References}

[1] Acemoglu, D., Johnson, S., \& Robinson, J. A. (2005). Institutions as a fundamental cause of long-run growth. Handbook of Economic Growth, 1, 385-472.

[2] Angrist, J. D., \& Pischke, J. S. (2008). Mostly harmless econometrics: An empiricist's companion. Princeton university press.

[3] Asfaw, A., Frohberg, K., James, K. S., \& Jtting, J. (2007). Fiscal decentralization and infant mortality: empirical evidence from rural India. The Journal of Developing Areas, 17-35.

[4] Barankay, I., \& Lockwood, B. (2007). Decentralization and the productive efficiency of government: Evidence from Swiss cantons. Journal of Public Economics, 91(5-6), $1197-1218$.

[5] Bardhan, P. (2002). Decentralization of governance and development. Journal of Economic Perspectives,16(4), 185-205.

[6] Barone, G. (2011). Sull'ampiezza ottimale delle giurisdizioni locali: il caso delle province italiane. Banca d'Italia.

[7] Besley, T., \& Case, A. (1992). Incumbent behavior: Vote seeking, tax setting and yardstick competition (No. w4041). National Bureau of Economic Research.

[8] Buonanno, P., \& Pazzona, M. (2014). Migrating Mafias. Regional Science and Urban Economics 44, 7581.

[9] Caglayan, M., Flamini, A., \& Jahanshahi, B. (2017). Organized crime and Technology. University of Pavia DEM Working Paper Series, (136).

[10] Cameron, A. C., \& Trivedi, P. K. (2005). Microeconometrics: methods and applications. Cambridge University Press. 
[11] Cavalieri, M., \& Ferrante, L. (2016). Does fiscal decentralization improve health outcomes? Evidence from infant mortality in Italy. Social Science \& Medicine, 164, $74-88$.

[12] Dalla Chiesa, N. (2017). Passaggio a Nord: la colonizzazione mafiosa. Associazione Gruppo Abele Onlus-Edizioni Gruppo Abele.

[13] Drezner, D. (2001). State structure, technological leadership and the maintenance of hegemony. Review of International Studies, 27(1), 003-025.

[14] Eaton, J., Kortum, S., \& Lerner, J. (2004, October). International patenting and the European Patent Office: A quantitative assessment. In Patents, innovation and economic performance: OECD conference proceedings (pp. 27-52). Paris: OECD Publishing.

[15] Europol (2013). Threat Assessment: Italian Organised Crime. The Hague.

[16] Feld, L. P., Zimmermann H., \& Dring, T. (2004). Federalism, decentralization, and economic growth. ZBW WP 30/2004.

[17] Fisman, R., \& Gatti, R. (2002). Decentralization and corruption: evidence across countries. Journal of Public Economics, 83(3), 325-345.

[18] Huther, J., \& Shah, A. (1998). Applying a simple measure of good governance to the debate on fiscal decentralization (Vol. 1894). World Bank Publications.

[19] Lucas Jr, R. E. (1988). On the mechanics of economic development. Journal of monetary economics, 22(1), 3-42.

[20] De Mello, L., \& Barenstein, M. (2001). Fiscal decentralization and governance: A cross-country analysis (No. 2001-2071). International Monetary Fund.

[21] Musgrave, R. A. (1959). The Theory of Public Finance. McGraw-Hill: New York, 1959.

[22] Oates, W. (1972). Fiscal Federalism. Harcourt-Brace, New York, 1972. 
[23] Prud'Homme, R. (1995). The dangers of decentralization. The World Bank Research Observer, 10(2), 201-220.

[24] Prud'homme, D. (2016). Dynamics of China's provincial-level specialization in strategic emerging industries. Research Policy, 45, 1586-1603.

[25] Robalino, D. A., Picazo, O. F., \& Voetberg, A. (2001). Does fiscal decentralization improve health outcomes? Evidence from a cross-country analysis. The World Bank.

[26] Rodriguez-Pose, A., \& Ezcurra, R. (2010). Does decentralization matter for regional disparities? A cross-country analysis. Journal of Economic Geography, 10(5), 619-644.

[27] Romer, P. M. (1990). Endogenous technological change. Journal of political Economy, 98(5, Part 2), S71-S102.

[28] Scognamiglio, A. (2018). When the mafia comes to town. European Journal of Political Economy, 55, 573-590.

[29] Sergi \& Lavorgna, A. (2016). 'Ndrangheta: The Glocal Dimensions of the Most Powerful Italian Mafia. Springer, 2016.

[30] Tanzi, V. (1995). Fiscal federalism and decentralization: A review of some efficiency and macroeconomic aspects (pp. 295-316). Washington DC: World Bank.

[31] Taylor, M. Z. (2007). Political decentralization and technological innovation: Testing the innovative advantages of decentralized states. Review of Policy Research, 24(3), 231-257.

[32] Tiebout, C. M. (1956). A pure theory of local expenditures. Journal of Political Economy, 64(5), 416-424.

[33] Treisman, D. (2000). The causes of corruption: a cross-national study. Journal of Public Economics, 76(3), 399-457. 
[34] Treisman, D. (2002). Decentralization and the Quality of Government. unpublished paper, Department of Political Science, UCLA. 
Figure 1: New provinces - 1992 reform

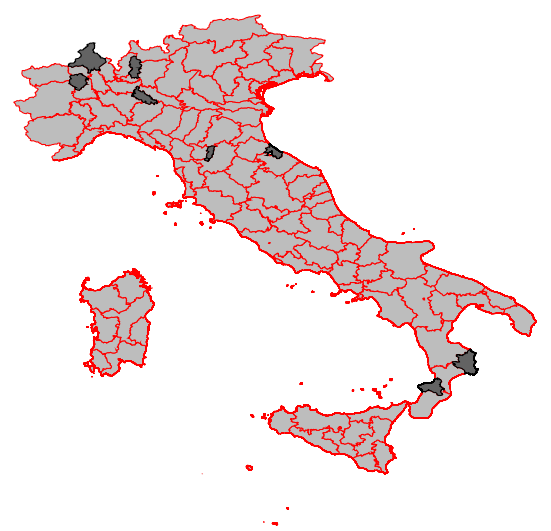

Figure 2: New provinces - 2001 reform

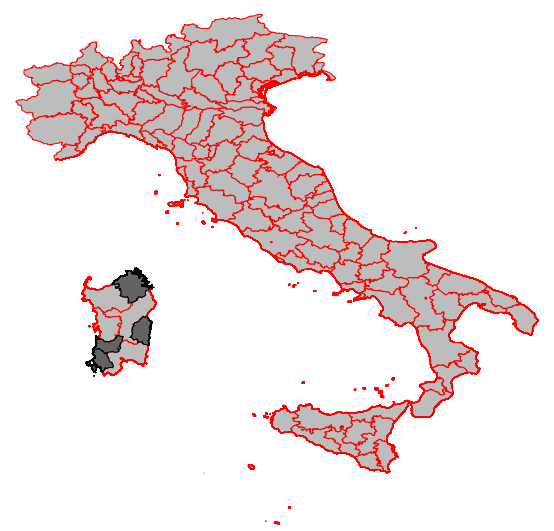

Figure 3: New provinces - 2004 reform

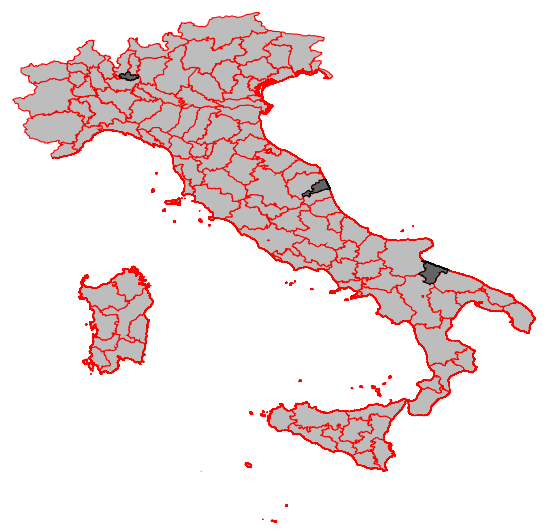


Table 1: Descriptive statistics on treated by reform wave

\begin{tabular}{lccc}
\hline \hline Province & Region & $\begin{array}{c}\text { Patent applications EPO } \\
\text { pre-treatment period }\end{array}$ & $\begin{array}{c}\text { Patent applications EPO } \\
\text { post-treatment period }\end{array}$ \\
\hline 1992 reform & & $1986-1992$ & $1993-1999$ \\
\hline Biella & Piedmont & 2.21 & 4.89 \\
Crotone & Calabria & 0 & 0.14 \\
Lecco & Lombardy & 3.29 & 14 \\
Lodi & Lombardy & 0.36 & 6.90 \\
Prato & Tuscany & 1.71 & 6.26 \\
Rimini & Emilia Romagna & 6.71 & 10.86 \\
Verbano-Cusio-Ossola & Piedmont & 1.64 & 4.79 \\
Vibo Valentia & Calabria & 0.07 & 0.14 \\
\hline 2001 reform & & $1995-2001$ & $2002-2008$ \\
\hline Carbonia-Iglesias & Sardinia & 0 & 0.67 \\
Medio Campidano & Sardinia & 0.36 & 0.14 \\
Ogliastra & Sardinia & 0.14 & 0.07 \\
Olbia-Tempio & Sardinia & 1.21 & 2.14 \\
\hline 2004 reform & & $1998-2004$ & $2005-2011$ \\
\hline Barletta-Andria-Trani & Apulia & 0 & 0 \\
Fermo & Marche & 0.14 & 3.36 \\
Monza and Brianza & Lombardy & 17.07 & 53.55 \\
\hline \hline
\end{tabular}


Figure 4: Parallel trends - 1992 reform

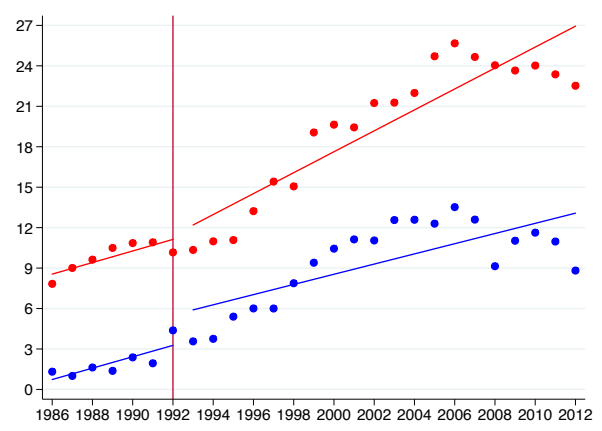

Note: Treated (blue) vs untreated (red).

Figure 5: Parallel trends - 2001 reform

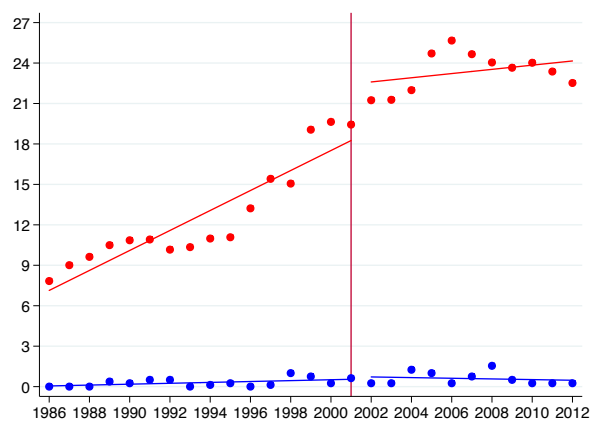

Note: Treated (blue) vs untreated (red).

Figure 6: Parallel trends - 2004 reform

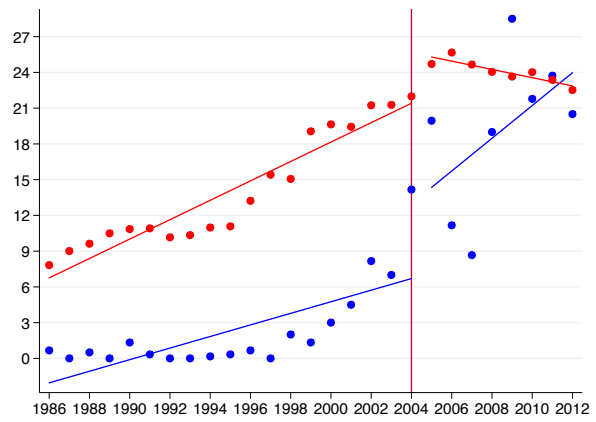

Note: Treated (blue) vs untreated (red). 
Table 2: Main results - average treatment effect

\begin{tabular}{lcccc}
\hline \hline & $($ i $)$ & $($ ii $)$ & (iii) & (iv) \\
\hline Treatment effect & $-11.16^{* *}$ & $-13.24^{* *}$ & $-19.25^{*}$ & $-6.51^{*}$ \\
& $(4.86)$ & $(5.52)$ & $(11.08)$ & $(3.80)$ \\
\hline Province FE & No & Yes & Yes & Yes \\
Year FE & No & Yes & No & No \\
Region $\times$ year FE & No & No & Yes & Yes \\
Exclusion of top5 & No & No & No & Yes \\
\hline Observations & 3,960 & 3,960 & 3,960 & 3,780 \\
Clusters & 110 & 110 & 110 & 105 \\
R-squared & 0.03 & 0.81 & 0.84 & 0.82 \\
\hline \hline
\end{tabular}

Note: Standard errors are robust and clustered at the province level. ${ }^{*},{ }^{* *}$, and ${ }^{* * *}$ denote significance at the 10,5 , and 1 percentage level, respectively. Top5 performers are Milan, Turin, Bologna, Rome, Vicenza.

Table 3: Main results - average treatment effect by reform wave

\begin{tabular}{lccccc}
\hline \hline & $($ i $)$ & (ii) & (iii) & (iv) & (v) \\
\hline Treatment effect 92 & $-9.68^{* *}$ & $-5.76^{*}$ & $-11.41^{*}$ & -0.25 & $-11.48^{*}$ \\
& $(4.20)$ & $(3.44)$ & $(6.09)$ & $(0.21)$ & $(6.17)$ \\
Treatment effect 01 & -1.11 & -0.86 & -0.26 & -0.26 & - \\
& $(0.88)$ & $(0.76)$ & $(0.20)$ & $(0.20)$ & - \\
Treatment effect 04 & -0.84 & 2.88 & -4.12 & -1.33 & -5.74 \\
& $(10.92)$ & $(11.44)$ & $(13.72)$ & $(2.85)$ & $(21.88)$ \\
\hline 1986-2012 time horizon & No & Yes & Yes & Yes & Yes \\
Exclusion of neighbor provinces & No & No & Yes & Yes & Yes \\
Northern-centre regions & Yes & Yes & Yes & No & Yes \\
Southern-centre regions & Yes & Yes & Yes & Yes & No \\
\hline Observations & 3,780 & 2,835 & 2,133 & 972 & 1,161 \\
Clusters & 105 & 105 & 79 & 36 & 43 \\
R-squared & 0.82 & 0.89 & 0.89 & 0.67 & 0.87 \\
\hline \hline
\end{tabular}

Note: Standard errors are robust and clustered at the province level. *, **, and ${ }^{* * *}$ denote significance at the 10,5 , and 1 percentage level, respectively. All specifications include province $\mathrm{FE}$ and region $\times$ year $\mathrm{FE}$, and exclude top5 performers (Milan, Turin, Bologna, Rome, Vicenza). Northern-centre regions include Emilia Romagna, Friuli Venezia Giulia, Liguria, Lombardy, Marche, Piedmont, Trentino Alto Adige, Tuscany, Umbria, Valle d'Aosta, Veneto. 
Table 4: Potential explanation: mafiosi in confino among Northern-Central provinces

\begin{tabular}{lccc}
\hline \hline & Above-median & Between median and 1st quartile & Below 1st quartile \\
\hline & $(\mathrm{i})$ & $($ ii $)$ & $($ iii $)$ \\
\hline Treatment effect 92 & $-17.74^{* *}$ & -10.73 & -1.11 \\
& $(7.91)$ & $(9.88)$ & $(9.60)$ \\
\hline Observations & 810 & 351 & 459 \\
Clusters & 30.00 & 13 & 17 \\
R-squared & 0.90 & 0.88 & 0.92 \\
\hline \hline
\end{tabular}

Note: Standard errors are robust and clustered at the province level. *, **, and ${ }^{* * *}$ denote significance at the 10,5 , and 1 percentage level, respectively. All specifications include province $\mathrm{FE}$ and region $\times$ year $\mathrm{FE}$, and exclude top5 performers (Milan, Turin, Bologna, Rome, Vicenza). Time horizon is 1986 - 2012. Estimates refer only to Northern-centre regions (Emilia Romagna, Friuli Venezia Giulia, Liguria, Lombardy, Marche, Piedmont, Trentino Alto Adige, Tuscany, Umbria, Valle d'Aosta, Veneto). New provinces in the "abovemedian" sample are: Lodi, Monza and Brianza. New provinces in the "between median and 1st quartile" sample are: Biella, Lecco. New provinces in the "below 1st quartile" sample are: Fermo, Prato, Rimini, Vebano-Cusio-Ossola. 
Table 5: Robustness checks

\begin{tabular}{|c|c|c|c|c|}
\hline & \multicolumn{2}{|c|}{ Placebo checks } & \multirow{2}{*}{$\begin{array}{c}\text { Time horizon } \\
\text { 1977-1992 } \\
\text { (iii) }\end{array}$} & \multirow{2}{*}{$\begin{array}{c}\text { Time horizon } \\
\text { 1986-2008 } \\
\text { (iv) }\end{array}$} \\
\hline & (i) & (ii) & & \\
\hline Placebo effect & $\begin{array}{c}0.81 \\
(3.99)\end{array}$ & & & \\
\hline Placebo effect 92 & & $\begin{array}{l}-3.22 \\
(3.85)\end{array}$ & & \\
\hline Placebo effect 01 & & $\begin{array}{c}0.86 \\
(0.76)\end{array}$ & & \\
\hline Placebo effect 04 & & $\begin{array}{c}9.71 \\
(13.81)\end{array}$ & & \\
\hline Mafiosi & & & $\begin{array}{c}-0.35 * * * \\
(0.13)\end{array}$ & \\
\hline Treatment effect 92 & & & & $\begin{array}{l}-9.20^{*} \\
(5.41)\end{array}$ \\
\hline Treatment effect 01 & & & & $\begin{array}{l}-0.06 \\
(0.36)\end{array}$ \\
\hline Treatment effect 04 & & & & $\begin{array}{c}-6.71 \\
(10.54)\end{array}$ \\
\hline Observations & 2,835 & 2,835 & 960 & 1,817 \\
\hline Clusters & 105 & 105 & 60 & 79 \\
\hline$R$-squared & 0.89 & 0.89 & 0.75 & 0.89 \\
\hline
\end{tabular}

Note: Standard errors are robust and clustered at the province level. *, **, and ${ }^{* * *}$ denote significance at the 10,5 , and 1 percentage level, respectively. All specifications include province $\mathrm{FE}$ and region $\times$ year $\mathrm{FE}$, and exclude top5 performers (Milan, Turin, Bologna, Rome, Vicenza). Time horizon in placebo checks is 1986-2012. Placebo reform 1992 involves the following provinces: Alessandria, Cosenza, Mantua, Novara, Pavia, Pistoia, Ravenna, Reggio di Calabria. Placebo reform 2001 involves the following provinces: Cagliari, Nuoro, Oristano, Sassari. Placebo reform 2004 involves the following provinces: Brescia, Foggia, Macerata. 
Table A1: Ranking of provinces (ascending order) by average patent applications at EPO over 1986 - 2012

\begin{tabular}{|c|c|c|c|c|c|}
\hline Position & Province & Patent applications EPO & Position & Province & Patent applications EPO \\
\hline 1 & Barletta-Andria-Trani & 0.04 & 56 & Latina & 7.64 \\
\hline 2 & Ogliastra & 0.06 & 57 & Palermo & 7.75 \\
\hline 3 & Crotone & 0.20 & 58 & Belluno & 7.88 \\
\hline 4 & Medio Campidano & 0.22 & 59 & Ascoli Piceno & 7.95 \\
\hline 5 & Vibo Valentia & 0.27 & 60 & Salerno & 7.96 \\
\hline 6 & Enna & 0.35 & 61 & Ferrara & 8.23 \\
\hline 7 & Carbonia-Iglesias & 0.36 & 62 & Prato & 8.84 \\
\hline 8 & Agrigento & 0.43 & 63 & Arezzo & 8.99 \\
\hline 9 & Caltanissetta & 0.52 & 64 & Vercelli & 9.22 \\
\hline 10 & Oristano & 0.62 & 65 & Bari & 10.29 \\
\hline 11 & Campobasso & 0.73 & 66 & Trieste & 10.90 \\
\hline 12 & Trapani & 0.74 & 67 & Catania & 10.92 \\
\hline 13 & Ragusa & 0.85 & 68 & Macerata & 11.29 \\
\hline 14 & Nuoro & 0.87 & 69 & Piacenza & 12.34 \\
\hline 15 & Syracuse & 0.94 & 70 & Chieti & 12.94 \\
\hline 16 & Matera & 0.96 & 71 & Cremona & 14.84 \\
\hline 17 & Olbia-Tempio & 1.04 & 72 & Perugia & 14.90 \\
\hline 18 & Reggio di Calabria & 1.10 & 73 & Rimini & 15.49 \\
\hline 19 & Fermo & 1.17 & 74 & Forl-Cesena & 17.71 \\
\hline 20 & Grosseto & 1.34 & 75 & Napoli & 18.00 \\
\hline 21 & Rieti & 1.48 & 76 & Venezia & 18.39 \\
\hline 22 & Isernia & 1.54 & 77 & Siena & 18.45 \\
\hline 23 & Foggia & $\begin{array}{l}1.64 \\
1.61\end{array}$ & 78 & Ravenna & $\begin{array}{l}10.40 \\
18.74\end{array}$ \\
\hline 24 & Catanzaro & 1.63 & 79 & Pesaro and Urbino & 18.78 \\
\hline 25 & Benevento & 1.73 & 80 & Pavia & 19.78 \\
\hline 26 & Sassari & 1.81 & 81 & Lecco & 20.70 \\
\hline 27 & Viterbo & 1.82 & 82 & Monza and Brianza & 20.73 \\
\hline 28 & Potenza & 1.87 & 83 & Lucca & 22.02 \\
\hline 29 & Avellino & 1.90 & 84 & Pisa & 22.99 \\
\hline 30 & Messina & 2.14 & 85 & Trento & 23.63 \\
\hline 31 & Cosenza & 2.26 & 86 & Mantua & 23.83 \\
\hline 32 & Imperia & 2.33 & 87 & Bolzano/Bozen & 24.24 \\
\hline 33 & Taranto & 2.46 & 88 & Cuneo & 25.31 \\
\hline 34 & Sondrio & 2.84 & 89 & Novara & 28.32 \\
\hline 35 & Valle d'Aosta/Valle d'Aoste & 3.02 & 90 & Alessandria & 29.12 \\
\hline 36 & Massa-Carrara & 3.03 & 91 & Udine & 40.54 \\
\hline 37 & Lecce & 3.62 & 92 & Como & 43.10 \\
\hline 38 & Verbano-Cusio-Ossola & 3.72 & 93 & Ancona & 43.11 \\
\hline 39 & Terni & 4.13 & 94 & Genoa & 45.74 \\
\hline 40 & Gorizia & 4.15 & 95 & Pordenone & 47.29 \\
\hline 41 & Caserta & $\begin{array}{l}4.10 \\
4.32\end{array}$ & 96 & Verona & 48.19 \\
\hline $\begin{array}{l}41 \\
42\end{array}$ & La Spezia & $\begin{array}{l}4.02 \\
4.32\end{array}$ & 97 & Parma & 50.30 \\
\hline 43 & Biella & 4.54 & 98 & Reggio nell'Emilia & 56.40 \\
\hline 44 & Cagliari & 4.58 & 99 & Varese & 58.41 \\
\hline 45 & Livorno & 4.80 & 100 & Florence & 70.72 \\
\hline 46 & Rovigo & 4.94 & 101 & Padua & 71.60 \\
\hline 47 & Teramo & 5.18 & 102 & Modena & 79.77 \\
\hline 48 & Brindisi & 5.33 & 103 & Brescia & 82.47 \\
\hline 49 & L'Aquila & 5.41 & 104 & Bergamo & 85.30 \\
\hline 50 & Savona & 5.43 & 105 & Treviso & 92.81 \\
\hline 51 & Pistoia & $\begin{array}{l}0.40 \\
6.04\end{array}$ & 106 & Vicenza & 111.60 \\
\hline 52 & Pescara & 6.08 & 107 & Roma & 140.97 \\
\hline 53 & Asti & 6.48 & 108 & Bologna & 190.51 \\
\hline 54 & Lodi & 6.60 & 109 & Turin & 257.15 \\
\hline 55 & Frosinone & 7.26 & 110 & Milan & 376.11 \\
\hline
\end{tabular}

Note: New provinces are listed in bold. 
Figure A1: Patent applications at EPO - averages by province over 1986-2012

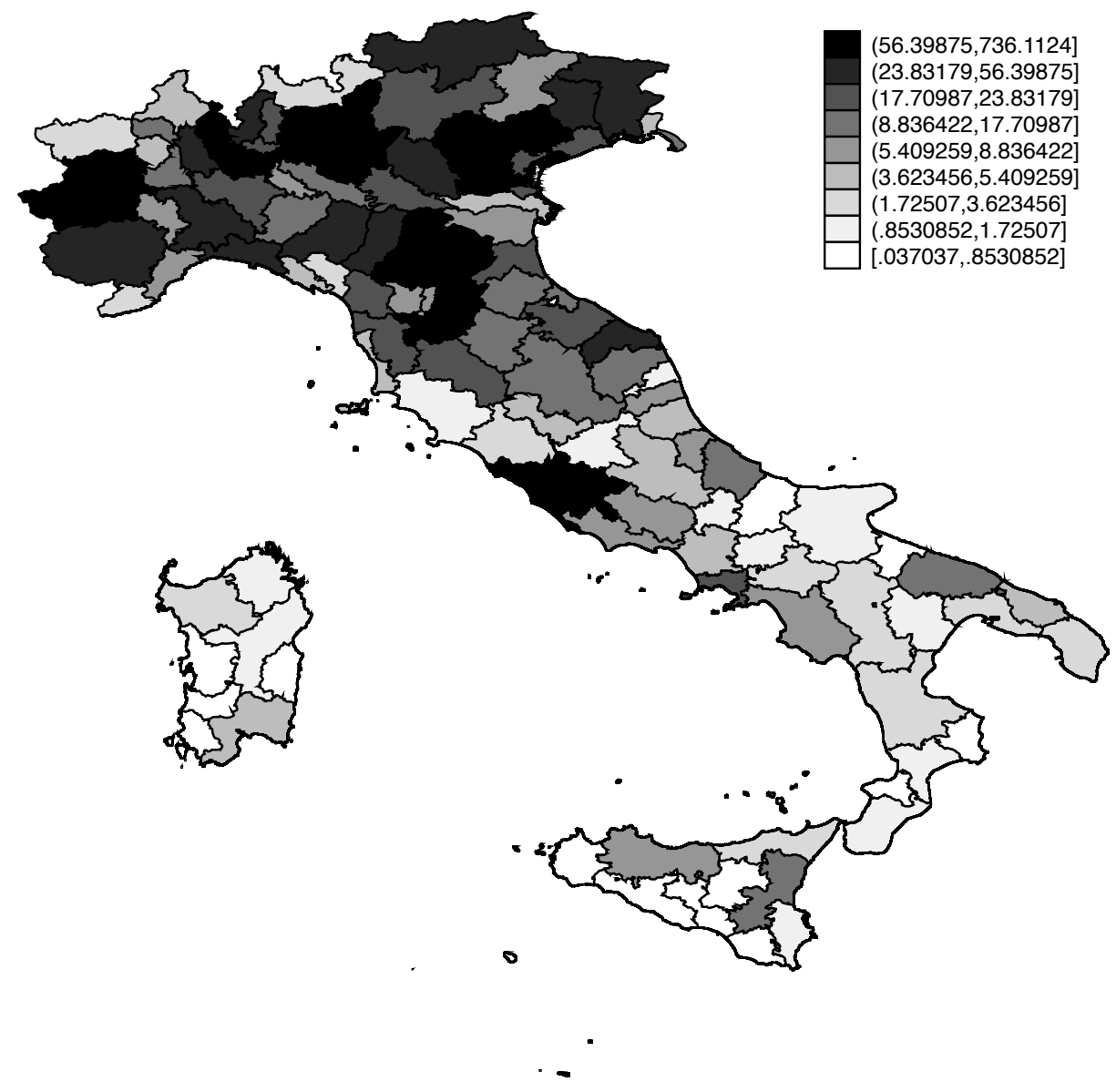

